\section{KOMPASS}

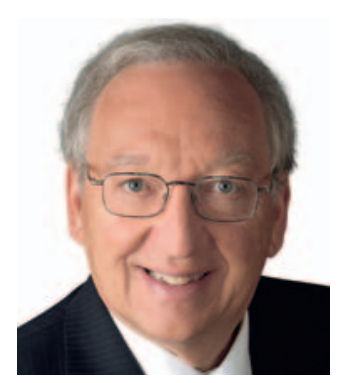

\section{Eberhart Zrenner}

Institute for Ophthalmic Research, Universität Tübingen

Karger Kompass Ophthalmol 2017;3:72-74

DOI: 10.1159/000472159

Beiträge zu

\title{
Behandlungsmöglichkeiten für Patienten mit erblichen Netzhautdystrophien
}

\author{
Ausgewählt und kommentiert von \\ Prof. Dr. Eberhart Zrenner (Tübingen)
}

Noch nie zuvor gab es so viele klinische Studien, die sich mit neuen Behandlungsmethoden bei degenerativen, erblichen Netzhauterkrankungen beschäftigen [1]. Weit gediehen sind der Einsatz der Genersatztherapie - auch mit neuartigen Applikationstechniken -, die Restitution mithilfe elektronischer Implantate und die Prävention durch Elektrostimulation.

\section{Genersatztherapie}

Bei noch ausreichend intakter Netzhaut helfen neue Robotik-unterstützte subretinale Injektionstechniken [2], um eine sichere subretinale Applikation auch bei schwierigen Fällen, wie etwa unter kleine makuläre Restinseln bei Chorioideremie [3], zu gewährleisten . PhaseIII-Studien bei Leberscher kongenitaler Amaurose sind erfolgreich abgeschlossen und eine Marktzulassung für diese Gentherapie steht bevor [4].

\section{Restitution}

Für blinde Patienten oder solche, die nur noch Lichtschein wahrnehmen, sind inzwischen elektronische Retina-Implantate auf dem Markt: sowohl epiretinale (Argus ${ }^{\circledast}$ I, Second Sight Medical Products Inc., Sylmar, CA, USA) [5] als auch subretinale (RETINA IMPLANT Alpha AMS, Retina Implant AG, Reutlingen, Deutschland) [6]. Sie erlauben in den meisten Fällen

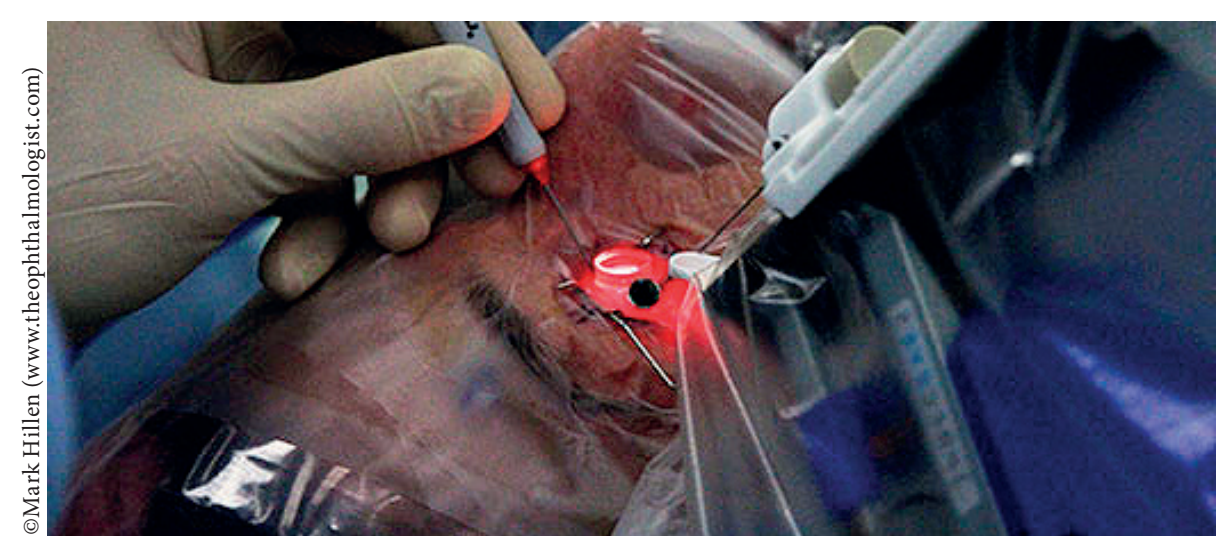

\section{KARGER}

Fax +4976145207 14 information@karger.com www.karger.com
(๑) 2017 S. Karger GmbH, Freiburg
Prof. Dr. Eberhart Zrenner

Institute for Ophthalmic Research

Universität Tübingen

Elfriede-Aulhorn-Straße 7, 72076 Tübingen, Deutschland

ezrenner@uni-tuebingen.de 
eine Restitution einer für den Alltag hilfreichen Sehleistung, die eine verbesserte Mobilität und Lokalisation von Gegenständen möglich macht. Im NUB(Neue Untersuchungs- und Behandlungsmethoden)-Verfahren werden diese Implantate von den gesetzlichen Krankenkassen finanziert. Gleichzeitig werden biologische Restitutionstechniken mit Stammzell-Applikation und Optogenetik erprobt [7].

\section{Prävention}

Zu einem überraschenden Ergebnis kamen zahlreiche Grundlagenstudien, welche die Wirkung von transcornealer Elektrostimulation mit wöchentlich 30-minütigen Wechselströmen auf die Freisetzung von endogenen Wachstumsfaktoren belegten. Wie neue klinische Studien zeigen, wirkt sich diese bei vielen Formen erbli- cher Netzhautdystrophien positiv auf die Funktion und den Krankheitsverlauf aus [8].

\section{Fazit}

Eine erbliche Netzhautdegeneration mit wahrscheinlicher Erblindung diagnostizieren zu müssen, ist sowohl für Augenärzte als auch für Patienten ein deprimierendes und schockierendes Ereignis. Durch neue Entwicklungen in der Ophthalmologie können jetzt aber für verschiedene Krankheitsbilder und -stadien Behandlungsmöglichkeiten genutzt oder für die Zukunft erwartet werden. Allerdings führt die ausgeprägte genetische Heterogenität und die damit verbundene Vielzahl von Krankheitsmechanismen dazu, dass nicht bei allen Patienten mit einem gleichen Behandlungserfolg gerechnet werden kann.

\section{Literatur}

1 Scholl HP, Strauss RW, Singh MS, et al.: Emerging therapies for inherited retinal degeneration. Sci Transl Med 2016;8:368rv6.

2 University of Oxford: World first for robot eye operation. www.ox.ac.uk/news/2016-09-12-worldfirst-robot-eye-operation (Zugriff 29.03.2017).

3 MacLaren RE, Groppe M, Barnard AR, et al.: Retinal gene therapy in patients with choroideremia: initial findings from a phase $1 / 2$ clinical trial. Lancet 2014;383:1129-1137.

4 Bennett J, Wellman J, Marshall KA, et al.: Safety and durability of effect of contralateral-eye administration of AAV2 gene therapy in pa- tients with childhood-onset blindness caused by RPE65 mutations: a follow-on phase 1 trial. Lancet. 2016;388:661-672.

5 Dagnelie G, Christopher P, Arditi A, et al: Performance of real-world functional vision tasks by blind subjects improves after implantation with the Argus ${ }^{\circledast}$ II retinal prosthesis system. Clin Exp Ophthalmol 2017;45:152-159.

6 Stingl K, Bartz-Schmidt KU, Besch D, et al.: Subretinal visual implant Alpha IMS - clinical trial interim report. Vision Res. 2015;111:149- 160.
7 Busskamp V, Duebel J, Balya D, et al.: Genetic reactivation of cone photoreceptors restores visual responses in retinitis pigmentosa. Science 2010;329:413-417.

8 Schatz A, Pach J, Gosheva M, et al.: Transcorneal electrical stimulation for patients with retinitis pigmentosa: a prospective, randomized, sham- controlled follow-up study over 1 year. Invest Ophthalmol Vis Sci 2017;58: 257-269.
MacLaren RE, Groppe M, Barnard AR, et al.: Retinal gene therapy in patients with choroideremia: initial findings from a phase 1/2 clinical trial. Lancet 2014; 383: 1129-1137.

Background: Choroideremia is an X-linked recessive disease that leads to blindness due to mutations in the CHM gene, which encodes the Rab escort protein 1 (REP1). We assessed the effects of retinal gene therapy with an adeno-associated viral (AAV) vector encoding REP1 (AAV.REP1) in patients with this disease.

Methods: In a multicentre clinical trial, six male patients (aged 35-63 years) with choroideremia were administered AAV.REP1 $(0 \cdot 6-1 \cdot 0 \times 1010$ genome particles, subfoveal injection). Visual function tests included best corrected visual acuity, microperimetry, and retinal sensitivity tests for comparison of baseline values with 6 months after surgery. This study is registered with ClinicalTrials.gov, number NCT01461213.

Findings: Despite undergoing retinal detachment, which normally reduces vision, two patients with advanced choroideremia who had low baseline best corrected visual acuity gained 21 letters and 11 letters (more than two and four lines of vision). Four other patients with near normal best corrected visual acuity at baseline recovered to within one to three letters. Mean gain in visual acuity overall was $3 \cdot 8$ letters (SE $4 \cdot 1)$. Maximal sensitivity measured with dark-adapted microperimetry increased in the treated eyes from $23 \cdot 0$ $\mathrm{dB}(\mathrm{SE} 1 \cdot 1)$ at baseline to $25 \cdot 3 \mathrm{~dB}(1 \cdot 3)$ after treatment (increase $2 \cdot 3 \mathrm{~dB}$ [95\%
CI $0 \cdot 8-3 \cdot 8])$. In all patients, over the 6 months, the increase in retinal sensitivity in the treated eyes (mean $1 \cdot 7$ [SE $1 \cdot 0]$ ) was correlated with the vector dose administered per $\mathrm{mm} 2$ of surviving retina $(\mathrm{r}=0 \cdot 82, \mathrm{p}=0 \cdot 04)$. By contrast, small non-significant reductions $(\mathrm{p}>0.05)$ were noted in the control eyes in both maximal sensitivity $(-0 \cdot 8 \mathrm{~dB}[1 \cdot 5])$ and mean sensitivity $(-1 \cdot 6 \mathrm{~dB}$ $[0 \cdot 9])$. One patient in whom the vector was not administered to the fovea reestablished variable eccentric fixation that included the ectopic island of surviving retinal pigment epithelium that had been exposed to vector.

Interpretation: The initial results of this retinal gene therapy trial are consistent with improved rod and cone function that overcome any negative effects of retinal detachment. These findings lend support to further assessment of gene therapy in the treatment of choroideremia and other diseases, such as age-related macular degeneration, for which intervention should ideally be applied before the onset of retinal thinning.

Stingl K, Bartz-Schmidt KU, Besch D, et al.: Subretinal visual implant Alpha IMS - clinical trial interim report. Vision Res 2015;111:149-160.

A subretinal visual implant (Alpha IMS, Retina Implant AG, Reutlingen, Germany) was implanted in 29 blind participants with outer retinal degeneration in an international multicenter clinical trial. Primary efficacy endpoints of the study protocol were a significant improvement of activities of 
daily living and mobility to be assessed by activities of daily living tasks, recognition tasks, mobility, or a combination thereof. Secondary efficacy endpoints were a significant improvement of visual acuity/light perception and/ or object recognition (clinicaltrials.gov, NCT01024803). During up to 12 months observation time twenty-one participants (72\%) reached the primary endpoints, of which thirteen participants (45\%) reported restoration of visual function which they use in daily life. Additionally, detection, localization, and identification of objects were significantly better with the implant power switched on in the first 3 months. Twenty-five participants (86\%) reached the secondary endpoints. Measurable grating acuity was up to 3.3 cycles per degree, visual acuities using standardized Landolt C-rings were 20/2000, 20/2000, 20/606 and 20/546. Maximal correct motion perception ranged from 3 to 35 degrees per second. These results show that subretinal implants can restore very-low-vision or low vision in blind (light perception or less) patients with end-stage hereditary retinal degenerations.

\section{Schatz A, Pach J, Gosheva M, et al.: Transcorneal electrical} stimulation for patients with retinitis pigmentosa: a prospective, randomized, sham- controlled follow-up study over 1 year. Invest Ophthalmol Vis Sci 2017;58:257-269.

Purpose: After promising results of an exploratory study, this study was designed to assess the safety and efficacy of transcorneal electrical stimulation (TES) over 1 year in patients with retinitis pigmentosa (RP).
Methods: We included $52 \mathrm{RP}$ patients in this prospective, randomized, partially-masked study which was done in accordance with rules of good clinical practice. Transcorneal electrical stimulation by Okustim was applied monocularly for 30 minutes per week for 52 consecutive weeks. Patients were assigned randomly to the groups: sham, $150 \%$, or $200 \%$ of individual electrical phosphene threshold (EPT). Visual acuity (retroilluminated Snellen charts), visual field (VF; Octopus 900), electroretinography (ERG), rod and cone full-field stimulus threshold, EPTs and IOP were assessed. Primary outcome measures were VF area; secondary outcome measures were development of ERG parameters.

Results: The application of TES was tolerated well. Dry eye symptoms (31 of 52 patients) were registered as the main adverse event. Throughout the study period, the VF area showed only a trend for prevention of VF loss in the $200 \%$ group (P 1/4 0.24). A significant improvement of light-adapted single flash b-wave was noted for the 200\% ( $<<0.0001)$ and 150\% (P 1/4 0.006) groups compared to the sham group. Tendencies of improved function were observed for scotopic b-wave amplitude for the $200 \%$ group (P $1 / 4$ 0.097). Other examination methods did not reach statistical significance.

Conclusions: The safety and acceptable tolerability of weekly TES self-administered by patients at home was confirmed over the course of 1 year. Objectively measured improvements in retinal function with ERG provide support for the potential benefits of TES for RP patients. 